\title{
Kari Spernes
}

Avdeling for lcererutdanning

Høgskolen i Østfold

E-post: kari.spernes@hiof.no

Hilde Sofie Fjeld

Avdeling for lcererutdanning

Høgskolen i Østfold

\section{Vilje, men manglende handlekraft - skolelederes forståelse av tospråklige faglæreres plass i skolens læringsfellesskap}

\section{Sammendrag}

Artikkelen undersøker hvilken verdi skoleledere tillegger tospråklig fagopplcring og hvilken betydning dette har for tospråklige faglereres deltakelse i skolens lceringsfellesskap. Minoritetsspråklige elever har, ved behov, rett til tospråklig fagopplæring av lærere som behersker elevenes førstespråk. Tidligere undersøkelser viser at tospråklige faglcerere i liten grad får mulighet til å bidra i planleggingen av leringsarbeidet $i$ skolen og at samarbeid mellom tospråklige faglerere og klasselcerere er mangelfullt eller ikke-eksisterende. Vi finner det verdifullt å undersøke skolelederes engasjement innenfor dette feltet. Artikkelen er basert på en studie som ser på sammenhengen mellom skolelederes kunnskap om og forståelse for skolens tospråklige fagopplcering og deres tilretteleggelse for de tospråklige faglcereres deltakelse $i$ skolens kollektive laringsfellesskap. Studien er gjennomført $i$ en stor norsk kommune i Sør-Norge, og det er foretatt intervjuer med kommunens skolesjef, rektor for kommunens tospråklige faglcerere og de ungdomsskolerektorene som oppga at de hadde tospråklige faglcerere. Undersøkelsen viser at skolelederne vier tospråklig fagopplæring lite oppmerksomhet og at det er dårlig samsvar mellom uttalte verdier og bruksverdier, altså mellom det skoleledere sier de er opptatt av og det de faktisk viser i praksis. Det er mye som tyder på at både skoleeier og skoleledere kan utnytte ressursene til tospråklig fagopplæring langt bedre dersom dette arbeidet gis større prioritet i kommunen og på skolene.

Nøkkelord: løeringsfellesskap, organisasjonskultur, skoleledelse, tospråklige faglcerere, verdier

\section{Abstract}

This article examines what value principals ascribe bilingual instruction and what impact this has on bilingual teachers' participation in the schools' learning community. Immigrant students have, if needed, the right to bilingual instruction by teachers who speak the pupils' first language. Previous studies 
show that bilingual teachers seldom are given the opportunity to participate in the planning of learning activities in schools and that cooperation between bilingual teachers and classroom teachers is inadequate or non-existent. We find it worthwhile to examine school managers' commitment in this field. This article draws on a study that examines the relationship between school leaders' knowledge and understanding of the school's bilingual subject teaching and their ability to facilitate the bilingual teachers' participation in the school's collective learning community. The study was conducted in a large municipality in southern Norway, and we did interviews with the municipality's school commissioner, the principal of the municipal bilingual teachers and all the secondary school principals who stated that they had bilingual teachers in their staff. The data show that school leaders devote little attention to bilingual teaching and that there is a mismatch between espoused values and values in use, i.e. between what the school leaders say are their concerns and priorities and what they actually do in practice. The findings suggest that both school owners and school leaders can make better use of the resources for bilingual instruction if this work is given greater priority in the municipality and in schools.

Keywords: learning community, organizational culture, bilingual teachers, values

\section{Innledning}

Mange skoler i Norge har en stor minoritetsspråklig elevgruppe, og migrasjonssituasjonen tyder på at det vil bli flere minoritetsspråklige elever framover. Mange av disse elevene har den første tiden behov for opplæring med en lærer som mestrer både elevenes morsmål og norsk (jf. Opplæringslova, 1998, §2-8). I de aller fleste tilfeller får elevene det som kalles tospråklig fagopplæring - altså ikke morsmålsopplæring, men opplæring med morsmålet som hjelp. De tospråklige faglærerne inngår som en del av elevenes helhetlige opplæringstilbud, og fra norske myndigheter er det en uttrykt forventning om samarbeid mellom ulike aktører i skolen for å sikre kvalitet på det opplæringstilbudet som gis (Kunnskapsdepartementet, 2010; Kunnskapsdepartementet, 2016). Tidligere studier har imidlertid vist at tospråklige faglærere ikke inngår som likeverdige deltakere i samarbeidet med klassefaglærere (Dewilde, 2013; Fjeld \& Spernes, 2015; Vedøy, 2008).

Ledere har stor innvirkning på hva som vektlegges og prioriteres i læringsarbeidet, hva som oppleves som verdifullt og viktig hos de ansatte, og hva som fører til gode resultater hos elevene (Peterson \& Deal, 1998; Robinson, Lloyd \& Rowe, 2008; Schein, 2010). Artikkelen tar for seg hvilken betydning lederes prioriteringer har for det tospråklige fagområdet. 
Problemstillingen lyder: Hvilken verdi tillegger skoleledere tospråklig fagopplcring, og hvilken betydning har dette for tospråklige faglereres deltakelse i lceringsfellesskapet?

Vi mener at lederes kunnskap om og kjennskap til et fagområde indikerer hvilke verdier de tillegger dette området, og vi søker å svare på problemstillingen gjennom følgende forskningsspørsmål:

- Hvilken kjennskap har skolelederne til skolens tospråklige faglærere og den tospråklige fagopplæringen?

- Hvordan tilrettelegger skoleledere for de tospråklige faglærernes deltakelse i skolens kollektive læringsfelleskap?

Vi har intervjuet skoleledere i en stor norsk bykommune; skolesjefen, rektoren som er ansvarlig for den tospråklige fagopplæringen og seks ungdomsskolerektorer. Skoleledernes kunnskap om og oppmerksomhet overfor det tospråklige fagområdet kan ha innvirkning på de tospråklige faglærernes bidrag til og kunnskapstilegnelse fra læringsfellesskapet (jf. Peterson \& Deal, 1998; Schein, 2010). Organisasjonsteori danner utgangspunktet for å forstå skoleledernes betydning for skolekulturen, og ledernes verdier er sentrale i denne sammenhengen. Vi finner det hensiktsmessig å skille mellom uttalte verdier og bruksverdier - hva skoleledere sier at de gjør og/eller hvordan de forklarer handlingene sine, og hva de faktisk gjør (Argyris \& Schön, 1996; Bang, 2011). Vi bruker teori om profesjonelt læringsfellesskap (Stoll \& Louis, 2007) for å forstå samarbeidskonteksten de tospråklige lærerne skal inngå i, og vi søker å forstå mulige hindringer når det gjelder tospråklige faglæreres deltakelse i fellesskapet ved å gjøre bruk av begrepet profesjonell kapital (Hargreaves \& Fullan, 2014).

\section{Tidligere forskning og vårt bidrag}

Nasjonalt og internasjonalt finnes det mye forskning innenfor skoleledelse (se f.eks. Møller \& Fuglestad, 2006) og noe forskning innenfor flerkulturell utdanning (se f.eks. Banks \& Banks, 2016). Det er imidlertid svært lite forskning på ledelse i flerkulturelle skoler (Andersen \& Ottesen, 2011; Andersen, 2013; Vedøy, 2008). Ifølge Andersen (2013) er dette i norsk skolesammenheng et felt som er på begynnerstadiet.

Andersen (2013) viser til forskning som peker på hvilke nye utfordringer skoler står overfor i forbindelse med økende innvandring (se Goodard, Billot \& Cranston, 2006; Vedøy \& Møller, 2007). Andersen (2014) understreker viktigheten av at skoleledere har flerkulturell kompetanse for å gi et fullverdig tilbud til minoritetsspråklige elever, og hevder at programmer som utdanner skoleledere ikke tar hensyn til at skolen etter hvert har fått et mangfold av språk 
og kulturer. Andersen og Ottesen (2011) mener det er umulig å gi skoleledere en enkel beskrivelse av hvordan de skal møte mangfoldet, men de framhever sentrale områder som viktige for utviklingen av en flerkulturell skole.

Menken og Solorza (2013) viser i en studie fra USA at det er store forskjeller på hvordan skoleledere prioriterer arbeidet med tospråklig opplæring. Skoleledere med liten flerkulturell kompetanse hadde en negativ oppfatning av tospråklige faglærere, og mente at disse hadde mangelfull engelskkompetanse og at det var for lite bruk av engelsk i timene deres. Skolelederne med flerkulturell kompetanse, derimot, verdsatte de tospråklige faglærernes arbeid, og sa at det var viktig å støtte disse lærerne. Menken og Solorza (2013) konkluderer med at skolelederes, og da spesielt rektorers, kunnskap om, forståelse for og engasjement i tospråklig fagopplæring har stor betydning for hvorvidt skolen lykkes med arbeidet rettet mot de minoritetsspråklige elevene, og at det derfor er viktig å skolere skoleledere innenfor dette feltet.

Utover det ovenstående har vi funnet svært lite forskning rettet mot skoleledelse i flerkulturelle skoler, og vi mener at denne studien bidrar med ny kunnskap om norsk skoleledelse i en flerkulturell kontekst.

\section{Teori}

Skoleledere kan bare indirekte påvirke elevenes læring, gjennom å lede det profesjonelle fellesskapet og utvikle en lærende og samarbeidende kultur. Forskning viser at denne indirekte påvirkningen kan være særdeles kraftfull og betydningsfull (Peterson \& Deal, 1998). Peterson og Deal (1998) hevder at det er opp til skolelederne å identifisere, forme og opprettholde sterke, positive, elevfokuserte kulturer. I slike kulturer deler personalet en felles målsetting, og de underliggende normene er kollegialitet, forbedring og hardt arbeid. De hevder videre at lederne er nøkkelen til å skape en slik kultur fordi de kommuniserer kjerneverdier ut til lærere og andre som arbeider med elevene. Peterson og Deal (1998) konkretiserer hvordan ledere kan skape en elevfokusert kultur blant annet gjennom det de sier og gjør, hvordan de verdsetter og anerkjenner dem som arbeider for å tjene elevene og skolens målsetting, hvordan de kommuniserer om skolens mandat og mening og hvordan de feirer personalets suksesser og oppnådde målsettinger. Også Schein (2010) framhever ledere som viktige kulturskapere. Han hevder at ledere sender sterke signaler om hva som er ønskelig og viktig gjennom det de systematisk retter oppmerksomhet mot, måler og kontrollerer. På denne måten kommuniserer de verdier og holdninger. Medlemmene vil i tillegg merke seg det ledere ikke vier tid og energi på. Ledere har en vesentlig betydning som rollemodeller, og den synlige atferden deres, hva de gjør og ikke gjør, hvordan de snakker om og til andre, sender signaler om verdier og holdninger til hele organisasjonen. 
Som nevnt, løftes ofte verdielementet fram som viktig i beskrivelsen av en organisasjonskultur og dens innhold (Bang, 2011). Verdi kan defineres som “[...] en vedvarende tro på at en spesiell handlemåte [...] er å foretrekke framfor en motsatt eller annerledes handlemåte [...]” (Rokeach, 1976, sitert i Bang, 2013 s. 331). I denne studien er vi opptatt av å finne ut hvilke verdier tospråklig fagopplæring og tospråklige faglæreres deltakelse i det kollektive læringsfellesskapet har for skolen, slik det uttrykkes gjennom skoleledernes kjennskap til og oppmerksomhet mot dette feltet. I den forbindelse finner vi det nyttig å skille mellom uttalte verdier vs. bruksverdier, altså hva skolelederne hevder at de tror på og sier at de gjør (uttalte verdier), og hva som faktisk er de operative verdiene og hvordan disse verdiene manifesterer seg gjennom måten lederne handler på (bruksverdier) (Bang, 2011).

Argyris og Schön (1996) hevder at de uttalte verdiene, som et individ bruker for å forklare handlingene sine, kan stå langt fra bruksverdiene eller de verdiene som styrer de faktiske handlingene. I vår sammenheng betyr det at det kan være diskrepans mellom det skoleledere hevder at de gjør, og det de faktisk gjør. Forskjellene mellom uttalt verdi og bruksverdi er ikke nødvendigvis et bevisst forsøk på å unnlate å fortelle sannheten. Ifølge Argyris og Schön (1996) er individet ofte ubevisst sine egne bruksverdier.

Forskning viser at det er sammenheng mellom lærernes profesjonelle samarbeid og elevenes resultater (Dufour \& Marzano, 2011). Et lærersamarbeid kan ta mange former og være mer eller mindre omfattende og forpliktende. Det er særlig de skolene som lykkes i å skape et tett, forpliktende samarbeid - et kollektivt læringsfellesskap - som ser ut til å kunne hente gevinst i form av bedre læringsresultater (Mendez, 2015; McCallum, 2013). Stoll og Louis (2007) beskriver et profesjonelt leringsfelleskap som et samarbeid mellom en gruppe lærere som deler erfaringene sine og som har et kritisk blikk på egen praksis. Lærerne har en reflekterende, inkluderende og læringsorientert måte å arbeide på, ikke bare som individer, men også i en større kontekst: i et kollektivt, profesjonelt fellesskap. Stoll og Louis (2007) framhever visse karakteristika som kjennetegner et effektivt og profesjonelt læringsfelleskap: felles visjoner og verdier, kollektivt ansvar for elevene, samarbeid om læring, individuell og kollektiv læring hos lærerne selv og åpenhet og gjensidig tillit. De hevder at et profesjonelt læringsfellesskap også kan strekke seg over profesjonsgrenser, og at det kan være fruktbart å inkludere alle som tar seg av elevens ulike behov i læringssituasjonen. Det samlede personalet forstås da som klassefaglærere, andre faglærere, spesialpedagoger, assistentfaglærere og andre assistenter.

Hargreaves og Fullan (2014) argumenterer for gyldigheten av begrepet profesjonell kapital. Begrepet operasjonaliseres gjennom humankapital, sosialkapital og beslutningskapital. Humankapital handler om faglærerens kunnskap og talent for å løse oppgaven - om å kunne faget, være flink med barn, forstå elevenes bakgrunn, kunne anvende og sile ny forskning og selv kunne utvikle seg og lære videre. Sosialkapital er kvaliteten og kvantiteten på 
den tilgangen faglæreren har på personer som kan ha positiv betydning for hans/hennes yrkesutøvelse. Sosialkapital øker ifølge Hargreaves og Fullan faglærerens mulighet for innflytelse. Beslutningskapital gjør faglæreren i stand til å ta veloverveide og kloke avgjørelser i situasjoner som krever godt skjønn.

\section{Metode}

I denne studien undersøker vi hvilken verdi skoleledere tillegger tospråklig fagopplæring og hvilken betydning dette har for tospråklige faglæreres deltakelse i læringsfellesskapet. Vi søker å finne svar på problemstillingen gjennom forskningsspørsmålene 1) hvilken kjennskap skolelederne har til skolens tospråklige faglærere og den tospråklige fagopplæringen og 2) hvordan skolelederne tilrettelegger for de tospråklige faglærernes deltakelse i skolens kollektive læringsfelleskap. Vi ønsker gjennom studien ikke bare å forstå, men eventuelt også bidra til endringer i skolen (jf. Cohen \& Manion, 1994; Hammersley \& Atkinson, 1996).

Studien bygger på kvalitative intervjuer av skoleledere i en stor norsk bykommune i Sør-Norge, hvor cirka 14 prosent av innbyggerne har innvandrerbakgrunn. Skolelederne er kommunens skolesjef, en rektor som har ansvar for tospråklige faglærere, samt seks av kommunens åtte ungdomsskolerektorer. De seks ungdomsskolerektorene ble valgt fordi de oppga at de hadde elever med vedtak om tospråklig fagopplæring. Skolene er ulike i størrelse. Antall minoritetsspråklige elever på skolene avhenger i hovedsak av skolenes beliggenhet, og varierer fra noen få prosent opp til cirka 20 prosent.

Ansvaret for den tospråklige opplæringen er delegert til rektor for en skole som driver primært med voksenopplæring. Rektoren har også personalansvar for de tospråklige lærerne, og det er herfra ressursene til de ulike skolene i kommunen blir fordelt og administrert. De tospråklige faglærerne arbeider kun med tospråklig fagopplæring for minoritetsspråklige elever. Rektoren ved denne skolen fordeler de tospråklige lærerne til de ulike grunnskolene i kommunen ut fra antall elever i de ulike språkgruppene. Grunnskolene får tildelt et visst antall timer med aktuelle tospråklige faglærere, og sammen forsøker grunnskolen og skolen for de tospråklige faglærerne å finne gode løsninger for tidspunkter de tospråklige lærerne skal være ved skolen. Det gjøres ikke avtaler utover undervisningstid. Den tospråklige faglæreren kan ha undervisning ved inntil ti forskjellige skoler i løpet av en uke.

Det ble utarbeidet en halvstrukturert intervjuguide (se appendiks 1) som etter ønske fra flere av informantene ble sendt dem cirka en uke i forkant av intervjuene. De overordnede temaene tok utgangspunkt i forskningsspørsmålene, og var: a) fakta og kjennskap til kommunens og skolens tospråklige fagopplæring, b) skolens kollektive læringsfellesskap og c) tospråklige faglæreres deltakelse i det kollektive læringsfellesskapet. 
Dataene ble samlet inn i løpet av to måneder høsten 2015. Intervjuene foregikk på skoleledernes kontor, og varte i cirka en time. Det ble tatt lydopptak av intervjuene, og disse ble transkribert i sin helhet. Analysen foregikk kontinuerlig gjennom prosessen (Hammersley \& Atkinson, 1996), og systematiseringen av dataene bygger i hovedsak på den tematiske inndelingen i intervjuguiden. Vi laget i tillegg en kategori som omhandlet begrepsbruk hos informantene. Dette gjorde vi fordi informantenes bevisste eller ubevisste valg av begreper, gjenspeiler deres kompetanse på og holdninger til feltet. Som analytisk verktøy tar vi utgangspunkt i begrepene uttalt verdi og bruksverdi (jf. Argyris \& Schön, 1996; Bang, 2011) og hvordan disse verdiene manifesterte seg hos skolelederne. Disse begrepene blir også sentrale i drøftingsdelen.

Alle navn er fiktive, og for ytterligere å anonymisere, presenteres alle informantene som hunkjønn. Resultatene viser i hovedsak til intervjuene med ungdomsskolerektorene og skolesjefen, mens intervjuet med rektoren som har ansvaret for de tospråklige faglærerne, brukes som et bakteppe.

\section{Analyse}

Analysedelen deles i to delkapitler. Det første delkapitlet presenterer hvilken kjennskap skolelederne har til kommunens og skolens tospråklige faglærere og den tospråklige fagopplæringen. Vi mener skolelederes kjennskap til eller manglende kjennskap til alt som vedrører tospråklig fagopplæring kan være uttrykk for hvordan de verdilegger dette fagområdet (jf. Schein, 2010). Det neste delkapitlet presenterer skoleledernes forståelse av det kollektive læringsfellesskapet og de tospråklige faglærernes deltakelse i dette.

\section{Skoleledernes kjennskap til de tospråklige faglærerne og den tospråklige fagopplæringen}

Vi vil her ta for oss hva skolelederne forteller om skolens tospråklige fagopplæring, hvilken kjennskap de har til de tospråklige faglærerne, og hvordan de arbeider med dette fagområdet på skolen. Rektorene ga bestemt uttrykk for at tospråklig fagopplæring var viktig for de minoritetsspråklige elevene, og at tospråklige faglærere var en ressurs for elever, foreldre, lærere og skolens ledelse på grunn av deres språk- og kulturkunnskap. Flere av rektorene pekte på styrken i å ha tospråklige faglærere som kunne bidra i oversettelser og hjelpe til med å forstå de ulikhetene som hersker mellom norsk kultur og kulturer i hjemmet. En av rektorene fortalte: 
De [tospråklige faglærerne] utgjør en kompetanse for oss for da kan vi gå og spørre dem: "Hva, hvorfor skjer det, hvor langt kan vi pushe her, er det noen grenser vi bør holde oss unna?” Og det er klart det, at innenfor islam så er det også mange forskjellige retninger og det er klart det, at du får også en bevissthet rundt det som gjør at du på en måte er litt undrende, du er litt forsiktig, du spør: "Er det noen generelle ting her i forhold til den familien vi bør ta hensyn til, for vi synes at dette blir veldig spesielt?” Ja, du kan få en del sånne svar, og det er klart at det er mye enklere når du har lærere som er en del av personalet her, som har en viss kompetanse på dette for oss.

Det var altså stor enighet blant rektorene om at de tospråklige faglærerne har en viktig funksjon for å bistå som kulturformidlere. De var ikke like samstemte når det gjaldt verdien av det faglige arbeidet. De fleste mente at elevene hadde behov for den faglige hjelpen, men at ressursene var for små til at opplæringen fikk god effekt. En av rektorene sa at hun var usikker på verdien av den tospråklige fagopplæringen, ikke fordi den var uviktig, men som hun sa: "Den ene og en halv klokketimen som elevene får i uka, er bare en dråpe i havet, det burde vært mye mer.” Dette var et poeng som flere nevnte. En rektor sa at “tospråklig fagopplæring er veldig viktig for de minoritetsspråklige elevene", men hun sa også at hun var usikker på kvaliteten av denne opplæringen.

Dataene viser at flere rektorer er usikre på hvilke språkgrupper de har ved skolen, hvor mange elever som får tospråklig fagopplæring, hvor mange tospråklige faglærere de har, og disse lærernes stillingsprosent og kompetanse. Flere sjekket GSI-oversikten (Grunnskolens Informasjonssystem) i løpet av intervjuet for å være sikre, og mange av antakelsene de hadde, viste seg å være feil. For eksempel nevnte to av rektorene flere språkgrupper enn de i realiteten hadde. Én listet opp ti aktuelle språkgrupper på skolen, men av disse var det kun tre hun kunne finne i oversikten. I tillegg inneholdt oversikten to språk hun ikke hadde nevnt.

Det hersket også usikkerhet når det gjaldt stillingsprosenten til de tospråklige faglærerne. De fleste rektorene uttrykte seg noe vagt om temaet. Det var kun rektoren med den største gruppen minoritetsspråklige elever, som sa noe konkret om stillingsstørrelser, men også hun var usikker:

Når det gjelder de store språka våre, som for eksempel albansk så er Ariana her, hun er vel her i omtrent hele stillingen sin. Eh, når det gjelder kurdisk, et av disse arabiske språkene, så er vel ho Kani her i nesten hele stillingen. Og så varierer det fra femti prosent og nedover til noen få timer eller enkelttimer.

Rektorene kunne ikke si noe om hvordan den tospråklige fagopplæringen foregikk, men de fleste sa at de trodde at de tospråklige faglærerne både deltok i klassen, og at de underviste på grupperom. En av rektorene sier: 
Det er begge deler. Eh, noen steder så er de tospråklige lærerne inne, andre steder så tar vi dem ut, eller at det kan være begge delene også. Det kommer helt an på, ikke sant, både elevgruppa, og det kommer an på hvor mange elever det er. Det kommer an på om de kommer i fra flere trinn. Det kommer helt an på hvilke fag det dreier seg om.

Flere rektorer var upresise og usikre i bruken av begreper som er relatert til enkeltvedtak for minoritetsspråklige elever: særskilt norskopplæring, morsmålsopplæring og tospråklig fagopplæring. En av rektorene blandet konsekvent sammen begrepene særskilt norsk og tospråklig fagopplæring. En av grunnene til at rektorene i større eller mindre grad hadde vanskelig for å være presise, kan være at enkeltvedtak i disse fagene blir gitt med hjemmel i samme paragraf i Opplæringslova (1998, § 2-8).

Når det gjaldt lærernes kompetanse, visste rektorene hvilke klasselærere som hadde utdanning innenfor norsk som andrespråk og flerkulturell pedagogikk, men de fleste hadde liten kjennskap til hvilken utdanning de tospråklige faglærerne hadde. En av rektorene uttrykker usikkerhet når det gjelder de tospråklige faglærernes kompetanse: «Det har vært stilt spørsmål ved kompetansen, altså utdanningen til en del av morsmålslærerne.» Her kan det virke som om rektoren uttaler seg på vegne av flere; at det vært en generell usikkerhet om de tospråklige faglærernes kompetanse. Hvem hun eventuelt uttaler seg på vegne av, kommer ikke fram i intervjuet, men det er nærliggende å tro at det enten er rektorkollegiet eller lærerkollegiet. På spørsmål om kjennskap til de tospråklige faglærernes bakgrunn og utdanning svarer to andre rektorer:

Rektor 1: Ja, det er litt forskjellig, der må jeg neste høre med NN [ansvarlig for tospråklig fagopplæring] for å få nøyaktig bakgrunn der, men noen - i hvert fall én av dem - har pedagogisk bakgrunn.

Rektor 2: Ja - nei - altså, nå kjenner jo ikke jeg utdanningsbakgrunnen deres. Det gjør jeg ikke, så det kan jeg ikke uttale meg om.

At rektorene ikke kjente kompetansen til de tospråklige faglærerne, ble begrunnet med at de ikke hadde arbeidsgiveransvar for disse lærerne. Ingenting i rektorenes svar tilsier at de hadde tatt kontakt med skolen som administrerer ressursen til tospråklig fagopplæring for å få informasjon om de tospråklige faglærernes kompetanse.

Ved fem av skolene hadde enten en inspektør, en koordinator for elever med vedtak etter § 2-8 eller en spesielt interessert eller kvalifisert lærer ansvaret for den tospråklige fagopplæringen. Rektorene ga ingen begrunnelse for hvorfor de hadde delegert denne oppgaven til andre, men det kan være en indikasjon på rektors prioritering av tospråklig fagopplæring. En av rektorene, som de siste årene hadde delegert ansvaret til en inspektør, fortalte om en tidligere ansatt med spesiell interesse og ansvar for området: 
Astrid la noen premisser i forhold til hvordan vi skulle jobbe. Mye av det ho jobbet fram og øvde seg på her har blitt en type modell som ho har tatt med seg til den nye skolen - i forhold til hvordan organiseringen bør være.

Rektor fortalte videre at denne læreren hadde fått "mye myndighet”, og hun fikk mulighet til å tilrettelegge den tospråklige fagopplæringen slik hun ønsket. Slik vi forstår rektor, var dette en god modell, men den ble ikke videreført ved skolen da læreren sluttet. Det kan tyde på at arbeidet er personavhengig og ikke godt forankret på systemnivå. Skolesjefen pekte på viktigheten av at en i ledelsen, rektor eller inspektør, hadde ansvaret for å følge opp de tospråklige faglærerne: "Jeg tror det er kjempeviktig at det er en i ledelsen, ikke bare en eller annen lærer, som får en slik mentorrolle”. Hun sa at dette var viktig både av timeplantekniske årsaker og "for at den tospråklige læreren skal føle seg ivaretatt på ledelsesnivå”. Skolenes praksis avviker altså fra skolesjefens intensjoner.

Selv om alle rektorene praktiserte skolevandring, var det ingen som besøkte de tospråklige faglærerne. De involverte seg heller ikke på annen måte i de tospråklige faglærernes arbeid. En av rektorene tok selvkritikk på dette: "Jeg burde ha fulgt dem opp tettere og liksom hjulpet dem”. Hun var også den eneste som fortalte at tospråklig fagopplæring var et tema de tok opp i ukentlige teammøter. Kun en av rektorene sa at de tospråklige faglærerne hadde egen arbeidsplass. Rektorene var også usikre på om de tospråklige faglærerne hadde tilgang til skolens og klassenes læringsplattform på nett.

Intervjuene viser at rektorene var samstemte $\mathrm{i}$ sin vektlegging av de tospråklige faglærernes kunnskap om elevenes hjemmeforhold, kultur og språk. De sa også at behovet for faglig støtte er stort, men at verdien av tospråklig fagopplæring antakelig er liten på grunn av de begrensede ressursene og organiseringen av tilbudet. Generelt sett er vårt inntrykk at rektorene i liten grad kjenner de tospråklige faglærerne ved skolen, noe dette sitatet også viser: "Jeg husker ikke navnene, men det er i hvert fall tre-fire stykker nå som jeg kjenner igjen”. At de tospråklige faglærerne ikke forstås som en del av lærerkollegiet, vises også i rektorenes begrepsbruk. Det er et tydelig "vi-dem-perspektiv", og to av rektorene bruker begrepene "mine lærere" og "våre lærere" når de snakker om de lærerne som har fast tilhold på skolen, mens de tospråklige faglærerne omtales uten eiendomspronomen og navn. De fleste rektorene var også svært usikre på de tospråklige faglærernes kompetanse og utdanning. På samme måte hadde de fleste rektorene mangelfull kjennskap til hvordan opplæringen for elevene med vedtak foregikk. 


\section{Skoleledernes forståelse av det kollektive læringsfellesskapet og de tospråklige faglærernes deltakelse}

Dette delkapitlet omhandler kollektivt læringsfellesskap, og med det mener vi her både teamsamarbeid og arbeidet med skolens langsiktige utvikling.

\section{Teamsamarbeid}

Alle rektorene sa at samarbeid generelt var viktig, og de fleste framhevet teamet som den viktigste samarbeidsarenaen. Det ble også poengtert at ingen lærere kunne stå utenfor et teamfellesskap, og en av rektorene forklarte dette slik:

Det å være på teamet er helt avgjørende i forhold til å henge med på hva som skjer, det er der hverdagsdriftsgreia i skolen er, og når dem har mellomtimer sitter dem nesten alltid og utnytter sine smutthull til å kunne snakke sammen. Å være utenfor team her, er nesten som å være spedalsk.

Denne rektoren sa samtidig, på direkte spørsmål, at de tospråklige faglærerne var "utenfor teamet” og at samarbeidet var "sporadisk", "tilfeldig” og “ikkeorganisert”. Utsagnene under viser hvordan rektorene betegner teamsamarbeidet mellom klasselærerne og de tospråklige lærerne:

Rektor 1: De tar det når de kommer, så avtaler de seg imellom, og så mailer de hverandre og litt sånn

Rektor 2: Jeg tror at de møtes mellom timene og prater litt rundt elevene og gir informasjon på den måten.

Rektor 3: De [tospråklige faglærerne] setter seg ved siden av dem [klasselærerne] som de var sammen med og sånn. Så fort jeg ser de så er det liksom inntil de lærerne som de er med til vanlig. Så det er mye sånn. Jeg kaller det fluepapirinformasjon, sånn gnikker innpå hverandre og så får de informasjon ved at de er i nærheten av hverandre.

De fleste rektorene forstår samarbeid som et gjensidig ansvar mellom de tospråklige faglærerne og klasselærerne, mens rektor 3 beskriver samarbeidet som en enveisprosess der de tospråklige faglærerne henter informasjon fra klasselærerne ved å være i nærheten av dem, det denne rektoren kaller "fluepapirinformasjon". Slik vi tolker dataene, foregikk det ikke noen tilretteleggelse for samarbeidet fra ledelsens side. En av rektorene sa det slik: "Klasselærer sitter på arbeidsrommet sitt, og hvis de har ting som de ønsker å snakke om, så møtes de der”. Den tospråklige faglæreren må altså ta initiativ til kontakt og oppsøke klasselæreren på hennes kontor. Rektorenes beskrivelser kan tyde på at samarbeidet mellom klasselærerne og de tospråklige faglærerne også var knyttet til spesielle, begrensede temaer og situasjoner. For eksempel sa en av rektorene at det i hvert fall foregikk et samarbeid når elevene skulle ha en prøve.

Den tospråklige faglærerens begrensede tid og tilgjengelighet ved skolen ble brukt som forklaring på manglende teamsamarbeid. En av rektorene sa det slik: “De har knapt med tid. De kommer inn for å ta undervisning, så må de dra til 
neste skole”. To av rektorene oppga også klassefaglæreres tidspress som en årsak til at samarbeidet mellom de tospråklige faglærerne og klasselærerne var vanskelig å få til. Den ene rektoren sa at klasselærerne hadde mange å samarbeide med, så det ble lite tid igjen til de tospråklige faglærerne. Den andre rektoren sa at klasselærerne hadde mye undervisning, og at de i tillegg "hadde mer enn nok i den avsatte planleggingstiden, hvor de flyr på møter og planlegger også videre”. Selv om rektorene sa at de skulle ønske samarbeidet mellom klasselærerne og de tospråklige faglærerne var bedre, er det ingenting som tilsier at de prioriterte å sikre dette samarbeidet. Skolesjefen var derimot opptatt av at undervisningen til de minoritetsspråklige elevene ikke skulle nedprioriteres på skolene. Hun sa samtidig at det kunne være vanskelig å finne gode rutiner for samarbeidet mellom klasselærerne og de tospråklige faglærerne. Hun framhevet viktigheten av at klasselærerne og de tospråklige faglærerne snakket sammen slik at elevene fikk et helhetlig tilbud. Igjen har vi et eksempel på at skolesjefens tanker og intensjoner ikke var implementert rundt på skolene.

\section{Skolens felles utviklingsarbeid}

Faglæreres arbeid i et læringsfellesskap handler i tillegg til teamsamarbeidet om skolens langsiktige utviklingsarbeid. Både skolesjefen og rektorene sa at det var viktig å samarbeide om felles satsningsområder, og alle de seks ungdomsskolerektorene snakket engasjert og varmt om skoleutviklingsarbeidet ved sine egne skoler. Rektorene fortalte om metoder, modeller og strategier for å sørge for høy deltakelse fra skolens ansatte. På spørsmål om hvem som var deltakere i dette fellesskapet, svarte fem av seks rektorer "alle”. Flere poengterte den brede deltakelsen i personalet, og en av rektorenes utsagn er representativt for de andre: "Sånn som vi jobber her nå, så gjelder det [deltakelsen i skolens felles utviklingsarbeid] faktisk talt alle ansatte, ikke bare lærerne, men også assistenter og andre.” En annen rektor sa at også kontoransatte, helsesøster og det tverrfaglige teamet deltok. Selv om hovedtemaet for intervjuene var tospråklig fagopplæring og tospråklige faglærere, var det ingen som eksplisitt nevnte de tospråklige faglærere.

På spørsmål om hvilken plass de tospråklige faglærerne hadde i læringsfellesskapet på deres skole, svarte fire av ungdomsskolerektorene at de tospråklige faglærerne var fraværende i dette fellesskapet. Noen rektorer antok at de deltok på den skolen hvor de hadde størst stillingsprosent. Andre trodde at de tospråklige faglærerne hadde all samarbeidstid ved skolen der de var ansatt. De fleste rektorene ga uttrykk for at de ønsket at de tospråklige faglærerne deltok i skolens utviklingsarbeid, men sa at det ikke fantes føringer eller rutiner for praktisk gjennomføring. De var alle av den oppfatning at de tospråklige faglærerne hadde så mange skoler å forholde seg til at det ville være umulig for dem å delta i utviklingsarbeidet ved skolene. En av rektorene hadde imidlertid et forslag til hvordan dette kunne gjennomføres: "De burde kanskje ha fått lov til å velge seg en skole som de kunne følge i fellestida.” 
Skolesjefen sa at de tospråklige faglærerne i hovedsak deltok i læringsfellesskapet ved de skolene der de hadde undervisning, og at det var fellestid for alle tospråklige faglærere annenhver måned. Ifølge rektoren med personalansvar for de tospråklige faglærerne, var de tospråklige faglærerne tilstede på egen skole og deltok i utviklingsarbeid her to ganger i måneden.

Verken rektorene på ungdomsskolene eller skolesjefen hadde altså kjennskap til hvor de tospråklige faglærerne deltok i utviklingsarbeid. Det kan forklares med organiseringen og prioriteringen av den tospråklige fagopplæringen på kommunenivå. Alle informantene, både rektoren med personalansvar for de tospråklige faglærerne, ungdomsskolerektorene og skolesjefen, var usikre på om modellen for organisering av kommunens tospråklige fagopplæring var ideell. To av rektorene sa også at spørsmål knyttet til tospråklig fagopplæring "aldri var tema på rektormøter” i skolesjefens regi, mens fire av rektorene sa at det tidligere hadde vært møter om det og at det da hadde handlet om organisering eller ressursbruk. En av rektorene sa det slik:

Det [tema knyttet til tospråklig fagopplæring] har vært enten helt fraværende eller en økonomisk diskusjon og en praktisk gjennomføringsdiskusjon, nesten ikke en pedagogisk diskusjon.

En rektor sa at det hadde vært en gruppe som hadde vurdert alternative organiseringsmåter, men at arbeidet ikke hadde gitt resultater. Alle rektorene sa at den eksisterende organiseringen ga dårlige arbeidsforhold for de tospråklige lærerne, at det nesten var umulig å få til samarbeid og at den tospråklige kompetansen ble dårlig utnyttet. De sa også at det ble gjort lite fra skoleeiers side for å bedre praksisen. Bortsett fra én, uttrykte rektorene at de selv heller ikke hadde tatt initiativ til å bedre situasjonen, verken overfor skolesjefen eller i eget personale.

Skolesjefen, rektoren for de tospråklige lærerne og de fleste ungdomsskolerektorene mente bestemt at de tospråklige faglærerne ville ha utbytte av å delta i skolens felles utviklingsarbeid. En av rektorene sa først at tospråklige faglæreres deltakelse i fellestiden var avhengig av temaet for møtet, men endret etter hvert oppfatning:

Nå må jeg tenke meg litt om, om det er temaer vi har hatt som egentlig ikke skulle være til nytte for dem? Vurdering for læring er jo kjempenyttig for dem å vite noe om, og sosiale regler og retningslinjer burde de ha vært med å diskutere og få innblikk i.

Hun avsluttet med å løfte fram klasseledelse som et absolutt relevant tema. En annen rektor påpekte de tospråklige faglærernes manglende innflytelse på hvordan skolens kultur ble formet, og at de heller ikke fikk tilgang til verdifull kunnskap om skolen, slik som normer og regler, arbeidsformer, strategier og satsingsområder. En tredje påpekte noe av det samme da hun i forbindelse med personalets læring om nye metoder og strategier sa: "Jeg tror nok at de [de 
tospråklige faglærerne] også hadde trengt den verktøykassa”. Samtalene om de tospråklige faglærernes deltakelse i det kollektive læringsfellesskapet dreide seg, som vi her har vist, om hvorvidt de tospråklige faglærerne ville ha nytte av å delta.

Generelt viser dataene at det er lite systematisk samarbeid om det daglige arbeidet og at de tospråklige faglærerne er totalt fraværende i fora der det langsiktige utviklingsarbeidet diskuteres. Rektorene ønsker større deltakelse fra denne gruppen lærere, men avslører at de vet lite om hvilke føringer som gjelder for lærernes samarbeidstid i kommunen, og de innrømmer også at de selv har gjort lite for å sørge for at denne lærergruppen deltar i læringsfellesskapet. Forklaringene på manglende deltakelse både når det gjaldt teamsamarbeid og utviklingsarbeid var også her begrensete ressurser og kommunens organisering av det tospråklige opplæringstilbudet.

\section{Samsvar eller diskrepans mellom uttalt verdi og bruksverdi}

På bakgrunn av analysen vil vi her diskutere om det er samsvar eller diskrepans mellom uttalt verdi og bruksverdi, altså om og i tilfelle hvordan de uttalte verdiene kommer til uttrykk eller manifesterer seg i handlinger (jf. Argyris \& Schön, 1996; Bang, 2011). Vi drøfter først sammenhengen mellom hvordan skolelederne uttrykker verdien av tospråklig fagopplæring og deres fokus på og engasjement omkring tilrettelegging for denne opplæringen, slik det faktisk kommer til uttrykk gjennom kjennskap til de tospråklige faglærerne og arbeidet de gjør. Deretter drøfter vi hvordan skolelederne forstår verdien av de tospråklige faglærernes deltakelse i skolens felles utviklingsarbeid, og hvorvidt og hvordan skolelederne legger til rette for at de tospråklige faglærerne kan ha mulighet for å delta.

\section{Skolens tospråklige fagopplæring}

Det første forskningsspørsmålet søker å finne svar på skoleledernes kjennskap til skolens tospråklige faglærere og den tospråklige fagopplæringen. Når det gjelder de uttalte verdiene, nevner ungdomsskolerektorene spesielt det verdifulle i at de tospråklige faglærerne kjenner elevenes bakgrunn, og således anerkjenner de til dels disse lærernes humankapital (jf. Hargreaves \& Fullan, 2014). Både skolesjefen og rektorene uttrykker også at det tospråklige fagarbeidet er viktig for de minoritetsspråklige elevene. Dette forstår vi blant annet på bakgrunn av at alle informantene sier at ressursene til tospråklig fagopplæring er for liten i forhold til behovet. Når det gjelder kompetanse hos de tospråklige faglærerne, ser vi at det uttrykkes til dels stor tillit og anerkjennelse fra flere av informantene. Skolesjefen og rektorene uttrykker også at flerkulturell kompetanse og utdanning i norsk som andrespråk er av stor verdi i skolen. Den 
uttalte verdien er altså at tospråklig fagopplæring og kompetanse hos lærerne på dette feltet er viktig.

Ledere sender sterke signaler om hva som er viktig gjennom hva de prioriterer og hva de vier oppmerksomhet (Schein, 2010). Når det gjelder bruksverdier, viser analysen at skolesjefen bare til en viss grad har kjennskap til kommunens tospråklige fagopplæring, mens ungdomsskolerektorene i liten grad kjenner til dette arbeidet. Kommunens organisering, med en egen rektor for de tospråklige faglærerne, bidrar til at de andre rektorene engasjerer seg lite. En rektor har imidlertid ansvaret for elevenes helhetlige opplæringstilbud, og ungdomsskolerektorene kan derfor ikke, slik vi forstår det, forsvare sin manglende kunnskap ved å vise til kommunens organisering.

Rektorenes mangelfulle kjennskap til omfanget av vedtak etter § 2-8 på egen skole, hvilke tospråklige faglærere de hadde og disse lærernes stillingsprosent er uttrykk for bruksverdier. De visste heller ikke mye om de tospråklige faglærernes arbeidsoppgaver eller hvordan den tospråklige fagopplæringen foregikk. Ifølge Peterson og Deal (1998) er det viktig at skoleledere verdsetter og anerkjenner lærerne. Når rektorene har så liten kjennskap til de tospråklige faglærerne ved skolen, indikerer dette at de heller ikke fullt ut verdsetter og anerkjenner dem. Forklaringen på den manglende kunnskapen kan ligge i at de delegerer arbeidet med denne elevgruppen til en mellomleder eller en interessert lærer. Dette kan være tegn på manglende interesse eller engasjement for dette arbeidet fra rektorenes side, men vi kan ikke se bort fra at hensikten har vært å delegere ansvaret til ansatte med mer kompetanse enn dem selv. Noen av rektorenes manglende kjennskap til og ukorrekt bruk av fagspesifikke begreper innenfor feltet, tolker vi som tegn på lav kompetanse på området. Schein (2010) hevder at det skoleledere retter oppmerksomheten mot, forteller de ansatte hva som er viktig. Slik vi forstår rektorene, gis tospråklig fagopplæring og tospråklige faglærere lite oppmerksomhet, og dette kan sende signaler både til de tospråklige faglærerne selv og til det øvrige personalet om at dette arbeidet ikke er viktig.

Selv om skolesjefens og noen av rektorenes uttalte verdier var at de tospråklige faglærerne i kommunen har høy kompetanse, er det imidlertid diskrepans også på dette punktet. Rektorene sa at de kjenner lite eller ingenting til disse lærernes bakgrunn, og at de heller ikke har gjort noe aktivt for å skaffe seg denne kunnskapen. Den delen av humankapitalen som ifølge Hargreaves \& Fullan (2014) omhandler læreres faglige og pedagogiske kunnskap, er lite kjent hos rektorene.

Når det gjelder oppbygging av flerkulturell kompetanse hos det øvrige personalet, kunne vi heller ikke se at dette var prioritert fra skoleledelsen. Flerkulturell forståelse var ikke et tema for felles kompetanseheving i kommunens eller skolens læringsfellesskap. I elevfokuserte skolekulturer bidrar rektoren til at hele personalet har felles målsettinger og en felles kjernekultur (Peterson \& Deal, 1998). Slik vi forstår det, blir rektorenes mandat om å skape 
en likeverdig og elevfokusert skolekultur vanskelig å oppfylle når de tospråklige faglærerne og deres arbeid ikke verdsettes og anerkjennes.

\section{Tospråklige faglæreres deltakelse i det kollektive læringsfellesskapet}

Det neste forskningsspørsmålet søker svar på hvordan skolelederne tilrettelegger for de tospråklige faglærernes deltakelse i skolens kollektive læringsfellesskap. For å svare på dette presenterer vi vår tolkning av skoleledernes uttalte verdier når det gjelder samarbeidet mellom de tospråklige faglærerne og klasselærerne, og hvordan vi forstår deres bruksverdier gjennom måten de tilrettelegger for de tospråklige faglærernes deltakelse i det kollektive læringsfellesskapet.

Forskning viser at elever får bedre læringsresultater i skoler hvor det er et godt samarbeid mellom lærere som arbeider med de samme elevene og hvor det er gode forpliktende, kollektive læringsfelleskap (Dufour \& Marzano, 2011; Mendez, 2015; McCallum, 2013). Det var en uttalt verdi hos alle rektorene at teamsamarbeid var nødvendig for å gi et helhetlig tilbud til elevene, og at de tospråklige faglærerne bidro med viktig kunnskap for lærerne på teamet. I tillegg var det en uttalt verdi, hos både skolesjefen og rektorene, at skolens langsiktige utviklingsarbeid i det kollektive læringsfellesskapet var viktig, og at det var nødvendig med deltakelse og engasjement fra hele personalet. Det var også en uttalt verdi at tospråklige faglærere ville ha stort utbytte av å delta i skolenes utviklingsarbeid.

De tospråklige lærerne i vår studie fikk ikke mulighet til å delta rutinemessig i teamsamarbeid eller i felles utviklingsarbeid, noe som kan bety dårligere læringsutbytte for de tospråklige elevene (Dufour \& Marzano, 2011; Mendez, 2015; McCallum, 2013). Skolesjefen og rektorene ga i liten grad eksplisitt uttrykk for at de mente de tospråklige lærerne hadde kunnskap de kunne tilføre læringsfellesskapet. Skoleledernes manglende oppmerksomhet rundt tospråklig fagopplæring kan signalisere at arbeidet de tospråklige lærerne utfører, ikke anses som viktig (jf. Schein, 2010). Hargreaves og Fullan (2014) operasjonaliserer begrepet profesjonell kapital gjennom begrepene humankapital, sosial kapital og beslutningskapital. Rektorene kjente ikke til de tospråklige faglærernes humankapital, altså deres faglige bakgrunn og deres evne til å undervise elevene. De tospråklige faglærerne fikk heller ikke utviklet sin sosialkapital, de hadde liten tilgang på samarbeid med andre lærere, og rektor var så godt som fraværende for dem. Manglende innflytelse ga også de tospråklige faglærerne liten beslutningskapital, noe som hindret dem i å ta avgjørelser som kunne være viktige for de minoritetsspråklige elevene. De tospråklige faglærerne fikk derfor ikke anerkjennelse for sin profesjonelle kapital.

De minoritetsspråklige elevenes læringsutbytte er avhengig av faglærerens kunnskap, ferdigheter og engasjement, noe som forutsetter at læreren selv utvikler seg som lærer i fellesskap med andre lærere (jf. Stoll \& Louis, 2007). Når de tospråklige faglærerne ikke fikk delta i læringsfellesskapet rundt de 
minoritetsspråklige elevene, fikk de heller ikke bidratt i det kollektive ansvaret for disse elevens læring (jf. Stoll \& Louis, 2007). De minoritetsspråklige elevene ved de skolene som er representert i denne studien, får - slik vi forstår det - ikke maksimalt utbytte av den undervisningen de blir gitt.

Når vi oppsummerer fra delkapitlene om tospråklig fagopplæring og tospråklige faglæreres deltakelse i læringsfellesskapet, ser vi en tydelig diskrepans mellom rektorenes uttalte verdi og deres bruksverdi. Vi er usikre på om dette er bevisste forsøk på å framstå som mer vellykket innenfor dette området enn det de faktisk er. Argyris og Schön (1996) hevder at individet ofte er ubevisst sine bruksverdier, og at manglende samsvar mellom uttalte verdier og bruksverdier ikke nødvendigvis er et bevisst forsøk på å framstå som mer vellykket enn det de er. I enkelte tilfeller kan det se ut som rektorene kanskje er ubevisst sine bruksverdier og derfor ikke ser forskjellene mellom uttalt verdi og bruksverdi. For eksempel nevner rektorene, på spørsmål om skolens læringsfellesskap, overhodet ikke de tospråklige faglærerne før vi stiller konkrete spørsmål om det. Slik vi forstår det, ville de, dersom de var bevisste på de tospråklige faglærernes manglende deltakelse, uoppfordret ha forklart årsaken til hvorfor de ikke deltok i teamsamarbeid og det kollektive læringsfellesskapet.

\section{Avsluttende kommentarer}

I denne studien har vi forsøkt å svare på hvilken verdi skoleledere tillegger den tospråklige fagopplæringen. Selv om skolelederne enstemmig uttrykker at den tospråklige fagopplæringen er viktig, og at de tospråklige faglærerne gjør en uvurderlig jobb, viser handlingene deres at dette er et nedprioritert område. Skolelederne vier skolens tospråklige fagopplæring lite oppmerksomhet og engasjement. De tospråklige faglærerne får ikke brukt sitt potensial, og de minoritetsspråklige elevene får kanskje ikke det utbyttet av undervisningen som de ville fătt dersom de tospråklige faglærerne hadde fått delta i læringsfellesskapet. Det er også stor sannsynlighet for at de tospråklige faglærernes bundne arbeidstid kun består av undervisningstiden og en time møtetid annenhver uke på skolen der de er ansatt, noe som eventuelt tilsier at et stort antall arbeidstimer blir liggende uutnyttet og kommunale ressurser går på den måten tapt. Vi mener det er et lederansvar å invitere de tospråklige faglærerne inn i læringsfellesskapet, slik at de utnytter de ressursene skolen får tildelt, på en best mulig måte for elevenes læring og utvikling.

Vi ser at det er stor avstand mellom skoleledernes uttalte verdier og deres bruksverdier knyttet til tospråklig fagopplæring i denne kommunen. Selv om norske kommuner har ulik organisering av tospråklig fagopplæring, tror vi allikevel at en synliggjøring av diskrepansen mellom uttalt verdi og bruksverdi kan bidra til at det settes i verk tiltak som sikrer bedre ressursutnyttelse og bedre 
læringsvilkår for både elever og lærere. Således kan vi med denne studien kanskje også bidra til forandringer i skolen, til beste for de minoritetsspråklige elevenes opplæringstilbud (jf. Cohen \& Manion, 1994; Hammersley \& Atkinson, 1996). I videreutviklingen av denne forskningen ville det være interessant å høre de tospråklige faglærernes perspektiv når det gjelder deltakelse i og innflytelse på skolens profesjonelle læringsfellesskap. Disse perspektivene kan også bidra til at kommunen får kunnskap til å videreutvikle en helhetlig opplæring for de minoritetsspråklige elevene.

\section{Referanser}

Andersen, F. C. (2013). Leadership in a linguistically and ethnically diverse upper secondary school - Responding to challenges. Nordic Studies in Education, 33(1), 31-49. https://www.idunn.no/file/pdf/60022208/leadership_in_alinguistically_and_ethnically_diverse_uppe.pdf

Andersen, F. C. (2014). Multicultural schools and new demands on leadership. Journal of Education and Training Studies, 2(3), 1-15. doi: 10.11114/jets.v2i3.349

Andersen, F. C., \& Ottesen, E. (2011). School leadership and ethnic diversity: Approaching the challenge. Intercultural Education, 22(4), 285-299. doi: 10.1080/14675986.2011.617422

Argyris, C., \& Schön, D. A. (1996). Organizational learning II: Theory, method, and practice. Massachusetts: Addison-Wesley.

Bang, H. (2011). Organisasjonskultur. Oslo: Universitetsforlaget AS.

Bang, H. (2013). Organisasjonskultur: En begrepsavklaring. Tidsskrift for norsk psykologforening. 50(4), 326-336. http://www.psykologtidsskriftet.no/pdf/2013/326336.pdf

Banks, J. A., \& Banks, C.A.M. (2016). Multicultural education: Issues and perspectives (9. utg.). US: Wiley.

Cohen, L., \& Manion, L. (1994). Research methods in education. New York: Routledge.

Dewilde, J. (2013). Ambulating teachers - a case study of bilingual teachers and teacher collaboration (Doktoravhandling), Universitetet i Oslo.

DuFour, R., \& Marzano, R. (2011). Leaders of learning: How district, school, and classroom leaders improve student achievement. Bloomington, IN: Solution Tree Press.

Fjeld, H. S., \& Spernes, K. (2015). Ingen jevnbyrdighet tross gode intensjoner. Vilkår for samarbeid mellom klasselærere og tospråklige lærere. Norsk pedagogisk tidsskrift, 99(34), 233-243. http://www.idunn.no/npt/2015/03/

Goodard, T. J., Billot, J., \& Cranston, N. (2006). Decision-making by school principals: The impact of ethnocultural diversity. Paper presentert på Commonwealth Council for Educational Administration and Management (CCEAM). 12.-17. oktober, Nicosia, Kypros.

Hammersley, M., \& Atkinson, P. (1996). Feltmetodikk. Oslo: Ad Notam.

Hargreaves, A., \& Fullan, M. (2014). Arbeidskultur for bedre læering i alle skoler. Hva er nødvendig lcererkapital? Oslo: Kommuneforlaget.

Kunnskapsdepartementet. (2010). Tid til læring - oppfølging av Tidsbrukutvalgets rapport. (Meld. St.19 (2009-2010). https://www.regjeringen.no/no/dokumenter/Meld-St-1920092010/id608020/ 
Kunnskapsdepartementet. (2016). Fag - Fordypning - Forståelse - En fornyelse av Kunnskapsløftet. (St. Meld. 28 (2015-2016). https://www.regjeringen.no/no/dokumenter/meld.-st.-28-20152016/id2483955/

Leithwood, K., Seashore, K., Anderson, S., \& Wahlstrom, K. (2004). Executive summary: Review of research: How leadership influences student learning. The Wallace Foundation.

McCallum, D. A. (2013). Is there a relationship between teachers' classification of PLC implementation, teachers' rating of PLC effectiveness, and student achievement? (Doktoravhandling), Widener University.

Mendez, Y. (2015). Implementing transformational, professional learning communities in an urban elementary school: An autoethnographic case study (Doktoravhandling). Seton Hall University.

Menken, K., \& Solorza, C. (2013). Where have all the bilingual programs gone?!: Why prepared school leaders are essential for bilingual education. Journal of Multilingual Education Research, 4(3), 10-39. http://fordham.bepress.com/jmer/vol4/iss1/3

Møller, J., \& Fuglestad, O. L. (2006). Ledelse i anerkjente skoler. Oslo: Universitetsforlaget.

Opplæringslova. Lov om grunnskolen og den vidaregåande opplæringa (1998). https://lovdata.no/dokument/NL/lov/1998-07-17-61?q=oppl\%C3\%A6ringslova

Peterson, K. D., \& Deal, T. E. (1998). How leaders influence the culture of schools. Educational Leadership, 56(1), 28-30. doi: 10.1.1.476.976\&rep=rep1\&type=pdf

Robinson, V. M. J., Lloyd, C. A., \& Rowe, K. J. (2008). The impact of leadership on student outcomes: An analysis of the differential effects of leadership types. Educational Administration Quarterly, 44(5), 635-674. doi: 10.1177/0013161X08321509

Schein, E. H. (2010). Organizational culture and leadership (4. utg.). San Francisco, Calif.: Jossey-Bass.

Stoll, L., \& Louis, K. S. (Red.). (2007). Professional learning communities: Divergence, depth and dilemmas. Birkshire: McGraw-Hill Education.

Vedøy, G. (2008). "En elev er en elev”, “barn er barn” og “folk er folk” - Ledelse i flerkulturelle skoler (Doktoravhandling). Universitetet i Oslo. http://www.uv.uio.no/ils/forskning/publikasjoner/rapporter-ogavhandlingen/Gunn_Vedoy\%5B1\%5D.pdf

Vedøy, G., \& Møller, J. (2007). Successful school leadership for diversity. Examining two contrasting examples of working for democracy in Norway. Journal of International Studies in Educational Administration, 35(3), 58-67. 


\section{Appendiks 1}

\section{Intervjuguide}

Tema 1: Tospråklig fagopplæring

Hvordan foregår den tospråklige fagopplæringen ved skolen?

(antall minoritetsspråklige elever/timer til tospråklig fagopplæring, språkgrupper, tospråklige faglæreres bakgrunn og arbeidssituasjon, organisering, samarbeid mellom klasselærere og tospråklige faglærere)

\section{Tema 2: Kollektive læringsprosesser}

Kan du fortelle litt om hvordan dere jobber med skoleutvikling?

(teamsamarbeid og begrepene «kollektive læreprosesser» og «skolebasert kompetanseutvikling», læringsarenaer, deltakere, modeller for utviklingsarbeid, deltakelse og ledelsens ansvar for å sikre deltakelse)

Tema 3: Tospråklige faglæreres deltakelse i kollektive læringsprosesser

Kan du fortelle om de tospråklige faglærernes "plass” og deltakelse i skolens utviklingsarbeid?

(fora, hyppighet, eventuelle hinder for deltakelse, forventninger om deltakelse, viktigheten av at tospråklige faglærere deltar)

Tema 4: Tospråklige faglæreres lærerkapital

Hvordan opplever du/ hva tenker du om de tospråklige lærernes integrering i personalet generelt?

(tospråklige faglæreres generelle deltakelse/integrering i personalet, betydningen av: tospråklige læreres utdanningsbakgrunn fra andre land og Norge, tospråklige faglæreres kjennskap til den norske skolen, deres språkkompetanse, deres kulturbakgrunn) 